Available online on 15.12.2020 at http://jddtonline.info
Open Access to Pharmaceutical and Medical Research
unrestricted non-commercial use(CC By-NC), provided the original work is properly cited

Open $\odot$ Access

Research Article

\title{
Knowledge, Attitude, Practice and Associated Factors of Adult Population towards Blood Donation in Jigjiga Town, Somali Region, Ethiopia
} \author{
Shegere $^{1}$, Nisha Mary Joseph ${ }^{2 *}$, S. Palani ${ }^{3}$ \\ 1. Department Of Public Health, College Of Medicine and Health Sciences, Jijiga University, Ethiopia \\ 2. School of Pharmacy, College of Health Sciences, Addis Ababa University, Ethiopia \\ 3. School of Medicine, College of Medicine and Health Sciences, Jijiga University, Ethiopia
}

Abdireshid Dahir Jibrili ${ }^{1}$, Ahmed Mohammed ${ }^{1}$, Abdiwahab Hashi ${ }^{1}$, Muktar Omer ${ }^{1}$, Mekonin Meskelu

\begin{abstract}
Background: Secure supply of safe blood components, based on voluntary, non-remunerated blood donation, is an important national goal to prevent blood shortages. Nowadays, in many low- and middle-income countries, blood supply is critically inadequate. Sub-Saharan Africa, which has the highest maternal mortality rate in the world of 510 deaths per 100000 live births, also has the lowest blood donation rates. The donated blood plays a big role during surgery, accident, delivery cases and in many bleeding cases.

The aim of this work is to assess knowledge, attitude, and practice and associated factors of adult population towards blood donation in Jigjiga town, Eastern Ethiopia, 2019. A total of 20 kebeles, six was selected by simple random sampling. The sample size was calculated by using EPI info version 7.2 by considering power of $80 \%$, confidence level of $95 \%$, by taking the comprehensive knowledge of the study Participants towards voluntary blood donation of $43.5 \%$ fromstudy conducted in Harar town, giving total sample size of 416. Data was entered to EPI DATA version 3.1.0 and then exported to and analysis using SPSS version 22. Descriptive statistics was used then bivariate and multivariate logistic regression model was employed to determine the significancee.

Result: About 249(61.2\%), 318 (78.1\%), and 77 (18.9\%) study participants had adequate knowledge, good attitude and experience of blood donation. Those who were in college and higher education were 2.034 higher odds of knowledge towards blood donation relative to those in secondary and primary education. Study participants who were government employees and daily workers were $2.259(1.103,4.629)$ times more knowledgable to housewife, students. Study particpants age range between 18-30 have less knowledge towards blood donation 0.408 times. Participants who attended college and higher education were more likely to have good attitude towards blood donation. Those respondents who are college and higher education and secondary were 2.450 times more likely, 2.359to have good attitude towards blood donation compared to primary school 2.161 respectively. Participant's sex, education, and occupational status were found to be significantly associated with practice of blood donation. Being NGO worker is more likely to donate blood 8.167 higher than others. Male participants was more vulnarable to donate blood 5.245 times higher than female for blood do nation. In addition to this, those respondents who are graduated college and higher education were more likely to donate blood than others 3.247 .
\end{abstract}

Keywords: Knowledge, Attitude, Practice, Blood Donation, JigjigaTown, Ethiopia

Article Info: Received 07 Sep 2020; $\quad$ Review Completed 21 0ct 2020; $\quad$ Accepted 29 Nov 2020; Available online 15 Dec 2020

Cite this article as:

Jibril AD, Mohammed A, Hashi A, Omer M, Shegere MM, Joseph NM, Palani S, Knowledge, Attitude, Practice and Associated Factors of Adult Population towards Blood Donation in Jigjiga Town, Somali Region, Ethiopia, Journal of Drug Delivery and Therapeutics. 2020; 10(6):149-165 http://dx.doi.org/10.22270/jddt.v10i6.4456

*Address for Correspondence:

Nisha Mary Joseph, School of Pharmacy, College of Health Sciences, Addis Ababa University

\section{Abbreviations}

WHO World Health Organization

VBD Voluntry Blood Donation

KAP Knowledge Attitude Practices

PI Principal Investigator
HIV/AIDS Human Immunodeficiency Virus/ Acquired Immune Deficiency Syndrome

HBV Hepatitis B virus

$\mathrm{HCV} \quad$ Hepatitis $\mathrm{C}$ virus 


\section{BACKGROUND}

Blood transfusion is the transfer of blood or blood components from the donor into the bloodstream of the recipient. In both routine and emergency blood donation is a life-saving approach 1,2 . Blood loss may be due to varying serious conditions such as road traffic accidents, obstretic and gynecological hemorrhages, surgery, long-term therapies as well as anemia of medical or hematologic conditions or cancer and so blood transfusion is considered as a fundamental and essential element of the health care system $^{3}$. The donated blood can be life-saving for those who have lost a large amount of blood due to serious accidents, anaemic patients or persons with very low platelet counts and certain hematological disorders such as leukemia ${ }^{4}$. The use of stored blood started during World War 1 (19141919), but the first large scale blood bank was not established durring that time until 1947, in Chicago5. The Canadian surgeon, Major L.B Robertson, serving in Canadian ArmyMedical Corps in the first World War was responsible for introducing blood transfusion in the management of war injuriesin the British Army. Blood transfusion was generally accepted as the medical treatment of choice for severe blood loss by the end of the war6. All donated blood was tested for diseases ${ }^{7}$. The World Health Organization (WHO) recomends that all countries should focus on young people to achieve $100 \%$ of nonremunerated voluntary blood donation by 20208. According to WHO 2011 report 107 million blood donation were collected globally, half of these were collected in high-income countries,home to $15 \%$ of the world's population. in high-income countries,middle-income countries and low-income countries the blood donation rate was 49.2,12.5, and 4.0 donations per 1000 population,respectively. in low-income countries,up to $15 \%$ of blood transfusions are given to children lesser than five years of age,in high-income countries, patients above 65 years of age, are mostly transfused,which comes up to $76 \%$ of all transfusions9. About 234 million major operations are performed world wide every year; 63 million people undergo surgery for traumatic injuries, 31 million for treating cancers, 10 million for pregnancy-related complications for which blood transfusion is mandatory ${ }^{10}$. The national requirement for blood in Ethiopia is between 80,000 and 120,000 units per year, but only $44 \%$ is collected 11 . The World Health Organization (WHO) mentions that blood donation by $1 \%$ of the total population are generally the minimum needed to meet a nation's most basic blood requirements ${ }^{12}$.

Globally, there is a shortage of blood supply due to high blood demand and increase in medical treatment procedures requiring blood transfusion therapy particularly in developing countries. Maintaining an adequate and safe blood supply is an issue of concern to health planners, especially with increase in demand. Therefore, understanding level of knowledge, attitude, practice, and associated factors towards blood donation is essential. The prevalence of blood donation was less than satisfactory due to misconceptions, poor knowledge, and unfavourable attitude, prevalence of adequate knowledge towards blood donation was seen to be $60 \%$ in developing countries, blood donation rate in low-income countries considerably less than that in middle- and high-income countries 13,14. Globally yearly analysis showed that around 92 million unit blood donations were collected from all types of blood donors, the lowest levels of availability are seen in low and middle income conuntries,especially in Africa ${ }^{15}$. Worldwide people from all age groups require blood donation to support continuity of life and improve the life quality16. Worldwide practices of blood donation are increasing but still it is a big concern for many countries. Blood which is safe prevents blood born infections from the donor to the recipient. Blood donation rates in Africa accounts to 5/1000 populations compared with developed countries for instance in USA it is 47/1000.17. In Sub-Saharan African countries, there is a high need for blood transfusions due to maternal morbidity, malnutrition and communicable diseases such as malaria 18 . About $44 \%$ of maternal deaths in Africa are due to severe bleeding during and after childbirth ${ }^{19}$. There has been gross insufficient in access to blood safety in WHO's African region 20,21 . Bleeding can be caused by accidents, medical procedures or major surgery and pregnancy related complications.About 495,000 women die from bleeding associated with pregnancy and childbirth, which needs early medical attention ${ }^{22}$.

Blood donation is included as the main aspect of the preventive and therapeutic component of the health care 23. Donor eligibility, negative attitude and lack of education lead to blood shortage in various facilities ${ }^{24}$. In developing countries, the community gets around $40 \%$ of the blood banks supply and out of this, $60 \%$ is collected from paid blood source 25 . People think that they may develop complications from donating blood, a major misconception underlying the practice 26 . Annually, $25 \%-40 \%$ of Ethiopian mothers die due to lack of enough blood from donors ${ }^{27}$, making available safe blood at all health care centres reduces maternal death, which assures that the lives of every mother will not be be in danger in case of emergencies for lack of blood ${ }^{28}$. The need for blood and blood products is increasing in all parts of the world29,30. Despite the fact that the country's annual demand of blood was 250,000 units, the amount of blood collected from donors by 2014 was 88,000 units ${ }^{31}$. In Ethiopia, an integrated strategy for voluntary blood donation and recruiting a sufficient number of safe blood donors are major challenges ${ }^{32}$. The people in the developing countries have $60 \%$ of adequate knowledge towards blood donation, and blood donation rate in lowincome, middle-income, and high-income countries are 4.9, 46.8 and 11.7 per 1000 population, respectively33,34. On average, high income countries have 9 times higher donation rate compared to low income countries 35 . In Ethiopia Only $22 \%$ of blood is donated by VBD (voluntry blood donation) ; the country is classified among countries that have least number of VBD (Group C, countries with $<50 \%$ VBD).Voluntary, non-remunerated blood donations are the cornerstone of an adequate supply of blood and blood components 36,37 . Thus, the objective of this research will be to assess knowledge, attitude,and practice and associated risk factors towards blood donation among adult population in Jigjiga town, Eastern Ethiopia. Furthermore, no previous study conducted in Somali regional state as whole and particularly injigjiga town. This study tried to come up with the following major finding that fills the existing information gap on the level of knowledge, attitude, practice and associated factors towards blood donation by adult population of Jigjiga town(figure1). 


\section{Conceptual frame work}

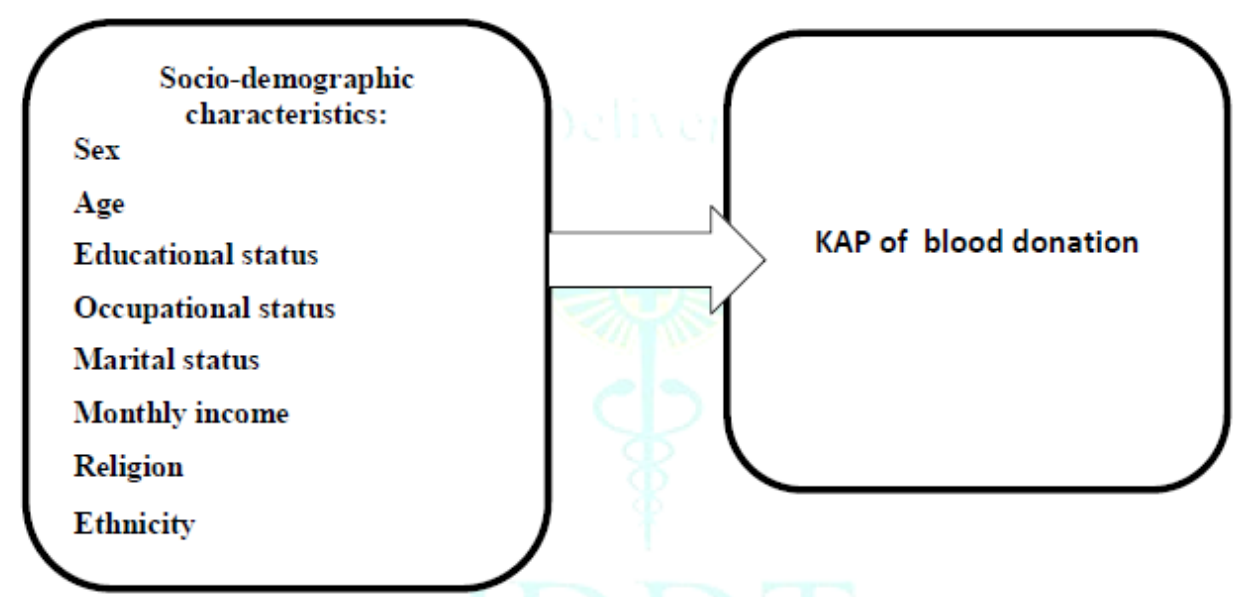

Figure 1: Conceptual framework of the KAP and associated factors of blood donation.

Source: Adapted from, after reading different artilces and Ghana University, Legon, 2017

The aim of this work was to assess knowledge, attitude, practice and asociated factors of adult population towards blood donation in jigjiga town Somali region, Ethiopia, 2019 with specific objectives as

(a) To assess the knowledge of blood donation among adult population in Jigjiga town.

(b) To assess attitude towards blood donation among adult population in Jigjiga town.

(c) To assess practice of blood donationamong adult population in Jigjiga town.

(d) To determine associated factors of knowledge, attitude and practice of blood donation.

\section{METHODS}

\section{Study area}

The study was conducted in jigjiga town which is the capital city of Somali regional state. Jigjiga is located south eastern of Ethiopia. It is situated at a distance of $\mathbf{6 2 8} \mathrm{km}$ away from Addis Ababa. It is 110 North latitude and 400 and 480 East longitude; the altitude of the town ranges from 200 to 1000 meters above sea level. The total population of the town is 967652 out of this 526497 are male and 441254 are female where $96.86 \%$ are Muslims.The town has one referal hospital, one regional hospital and two health centers respectively, unfortunately there is no blood bank in each regional and referal hospital, except one blood bank in somali regional state which is located in Jigjiga city.

\section{Study period}

Study was carried out in April, 2019.

\section{Study design}

Community based cross sectional study design was used.

\section{Population}

\section{Source population}

Source of population was all adult people living in Jigjiga town.

\section{Study population}

Study population was all adult people living in selected kebeles in Jigjiga town.

\section{Study unit ( subject)}

All selected individuals living in selected kebeles in Jigjiga town .

\section{Inclusion and exclusion criteria}

\section{Inclusion criteria}

All adult population aged between 18-65 years old (both male and female) who are willing to participate this study was included in the study.

\section{Exclusion criteria}

A study participant who has serious illness during the data collection period and unable to answer the questionaire was excluded from the study. Those people who were not mentally fit or had chronic diseases during the data collection time were excluded from this study.

\section{Sample size determination.}

\section{Sample Size for First Objective.}

The sample size of the first objective was determined using a single population proportion formula, by taking the comprehensive knowledge of the study participants towards voluntary blood donation of $43.5 \%$.from study conducted in harar town 38 . Using $95 \% \mathrm{CI}$ and $5 \%$ margin of error, the sample size was found to be 416(figure2) after considering $10 \%$ non-response rate

$$
n=\frac{(z \alpha / 2)^{2} p \times(1-p)}{\mathrm{d}^{2}}
$$

Where,

$\mathrm{n}=$ minimum sample size required for the study.

$\mathrm{Z}=$ standard normal distribution $(\mathrm{Z}=1.96)$ with confidence interval of $95 \%$ and $\alpha=0.05$

$\mathrm{P}=0.435$

$\mathrm{d}=$ Absolute precision or tolerable margin of error (d) $=5 \%=0.05$

$$
n=\frac{(z \alpha / 2)^{2} p \times(1-p)}{\mathrm{d}^{2}}=\frac{1.96^{2} \times 0.435(1-0.435)}{(5 \%)^{2}}=378
$$


The overall sample size was378 $+38(10 \%$ non-response rate) $=416$

\section{Sample Size for Second Objective.}

Sample size was calculated for factors associated with KAP of adult population towards blood donation, (table2) by considering various factors that were significantly associated with outcome variables with the following assumptions, twosided confidence level of $95 \%$ and power of $80 \%$. Using Epi Info 7 Stat Calc software for double population proportions formula, $10 \%$ for non response. (Table 1)

Table1: Displayed sample size determination for studying the Knowledge, Attitude, Practice and associated factors of Adult Population towards Blood Donation in Jigjiga Town, Somali region Ethiopia, 2019.

\begin{tabular}{|l|l|l|l|l|l|}
\hline SNO & Variable & exposed & Unexposed & AOR & Sample size(+10\% non-response rate) \\
\hline 1 & Gender (Male) & $25.8 \%$ & $42.1 \%$ & 1.68 & 317 \\
\hline 2 & Knowledge & $39.2 \%$ & $60.8 \%$ & 1.40 & 202 \\
\hline 3 & Educational status(higher education) & $66.7 \%$ & $33.3 \%$ & 2.88 & 88 \\
\hline
\end{tabular}

Finally, the required sample size for this particular study will be decided by taking the maximum sample size from first objective which is 416 .

\section{Sampling technique}

Out of twenty kebeles of Jigjiga town, six kebele was selected by using simple random sampling. Then the sample size was allocated proportionally to the households of the kebeles. After that systematic random sampling technique was used to select households. Finally, lottery method was employed to select one study participant from selected households with more than one eligible individuals (aged 18-65 years old). The selected individual was checked for two times if absent.

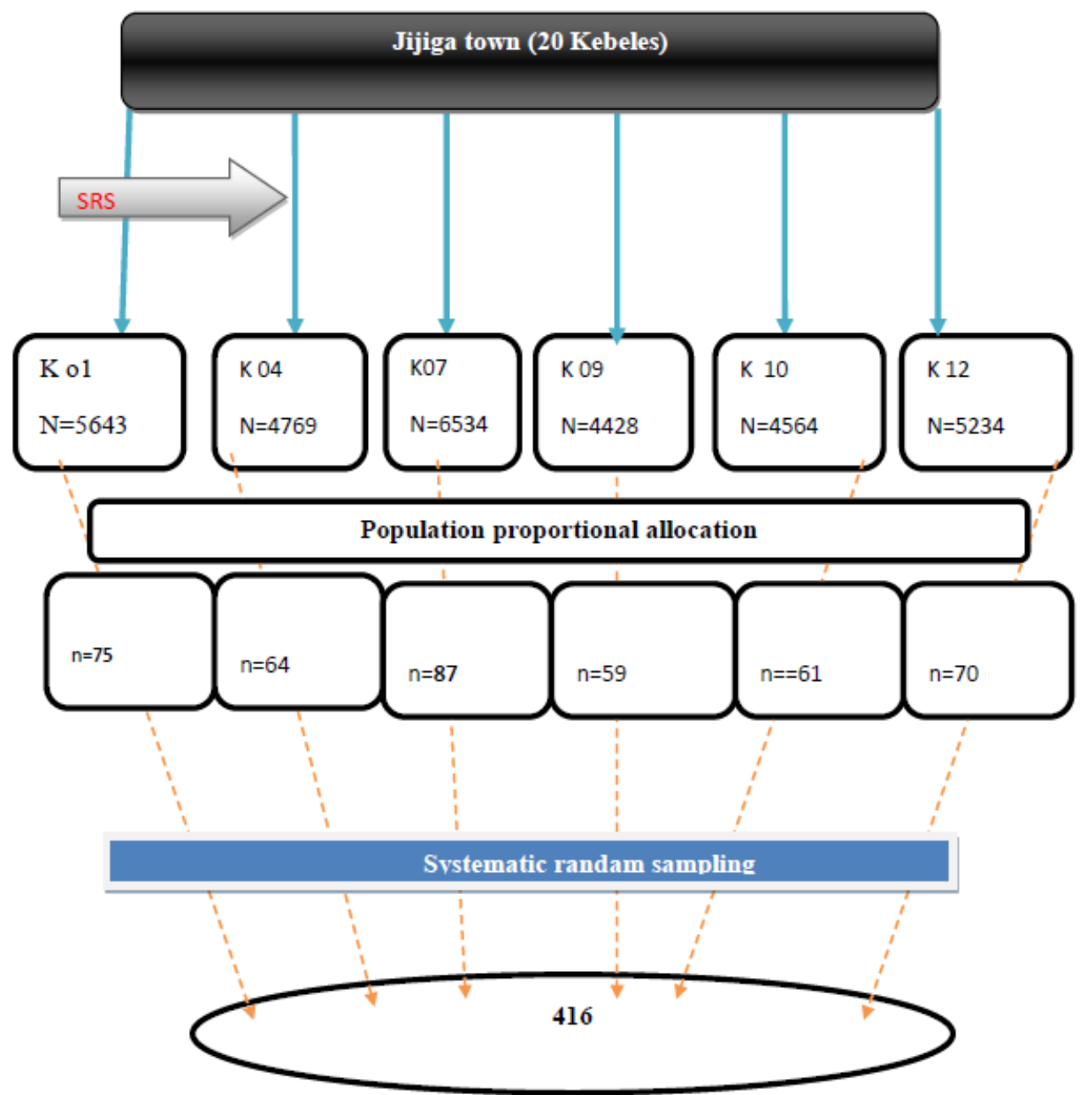

Figure 2: Schematic diagram of sampling procedure of jigjiga town. 


\section{Data collection instruments}

Data was collected by using interview questionnaire which was prepared in English and was translated to Somali language.The questionnaire includes socio-demographic factors, knowledge, attitude and practice. Six BSc Nursing were recruited for data collection. Data collectors were trained for one-day by principal investigator.

\section{Study variables}

\section{Dependent variables}

Knowledge ,attitude ,practice of blood donation

\section{independent variable}

Sociodemographic factors

Age

Sex

Ethnicity

marital status

Religion

Marital status

Educational status

Monthly income

Occupational status

\section{Data quality control}

For assuring the quality of the data, structured and pretested questionnaire was used. Pretest of the questionnaire was employed prior to actual data collection period among $5 \%$ of the study sample on one Kebele not included in this study by simple random sampling. During the pre-test, the questionnaire was assessed for its clarity, reliability, sensitivity of the subject matter and for cultural acceptability in the area,findings and experiences from the pre-test was utilized to modify the tools. The final version of the questionnaire which was prepared in English was translated into the local languages of the respondents (Somali and amharic languages) and again translated back to English. The data collectors and supervisors were given oneday intensive training by principal investigator (PI) on the instruments, method of data collection, how to store and keep the collected data . During the data collection process, supervision was conducted strictly and frequently. After the collection of data, completeness of the required type of data was checked for accuracy and consistency before the entry of data to the EPI-DATA and SPSS as well as during entry time and using simple frequency. Skip patterns command was used as one way of quality assurance during data entry.

\section{Data processing and analysis}

After the collection of data, the researcher checked the completeness of questionnaires and incomplete questionnaires were excluded; responses were coded, cleaned and entered into EPI DATA version 3.1.0 and it was exported and analysed using the Statistical Package for Social Sciences (SPSS) version 22.Then descriptive statistics was generated first and results was shown in tables, percentages, charts, mean and standard deviation and then by using inferential statistics, bivariate logistic regression analysis were performed. A variable with $\mathrm{p}$ values below 0.05 in the bivariate analysis was considered as candidate variable for multivariate logistic regression. P-values lower than $0.05,95 \%$ confidence interval and adjusted odds ratio were used to determine level of significance of association in multivariate logistic regression model and hosmer and lame show goodness of fit was checked.

\section{Ethical consideration}

The research topic was approved by school of graduate studies ethical committee of JU and the research proposal was submitted to JU then the ethical clearance was obtained from school of graduate studies. Permission to conduct the study was also obtained from Jijiga City administration. Verbal informed consent was given and then Data collection was conducted after explaining the aim of the study, confidentiality and its possible benefits to the participant Measures were taken to ensure the respect, dignity and freedom of each individual participating in the study. Health education and awareness creation on importance of blood donation was given.

\section{RESULT}

\section{Socio-Demographic Characteristics of Respondents}

From a total of 407 participants, 208 (51\%) were females and $199(48.9 \%)$ were males.Majority of the participants $((n=231(56.8 \%))$ were in the age range of $18-30$ years. The mean age of study participants was 28.34 \pm 8.704 SD years.Majority of the study particpants were married 253(62.2\%), single 147(36.1) respectively. Regarding to ethnicity, majority of the participants were Somali 393(96.6\%).About $123(30.2 \%)$ respondents were illiterate, while $48(11.8 \%), 99(24.3 \%)$ and $137(33.7 \%)$ of the study participants had attained primary, secondary and higher education, respectively.Most of the study participant were Islam religion followers $403(99.0 \%)$ and rest of the respondents followed by Orthodox $2(0.5 \%)$, Others 2 $(0.5 \%)$. According to occupational status of the study participants were house wife 155(38.1\%) (Table 2). 
Table 2: Description of socio demographic characteristics of adult population living in Jigiga town (n=407), Ethiopia, 2019.

\begin{tabular}{|c|c|c|c|c|}
\hline S.N & Variable & Category & Frequency $(\mathrm{n}=407)$ & Percentage (\%) \\
\hline \multirow[t]{4}{*}{1} & & 18-30yrs & 231 & 56.8 \\
\hline & Age & & & \\
\hline & & 31-45yrs & 126 & 31 \\
\hline & & $>45 y r s$ & 50 & 412.3 \\
\hline \multirow[t]{2}{*}{2} & Gender & Male & 199 & 48.9 \\
\hline & & Female & 208 & 51 \\
\hline \multirow[t]{4}{*}{3} & Marital status & Married & 253 & 62.2 \\
\hline & & Single & 147 & 36.1 \\
\hline & & Divorced & 5 & 1.2 \\
\hline & & Widowed & 2 & 0.05 \\
\hline \multirow[t]{4}{*}{4} & Ethnicity & Somali & 393 & 96.6 \\
\hline & & Oromo & 3 & 0.7 \\
\hline & & Amhara & 4 & 1 \\
\hline & & Others & 7 & 1.7 \\
\hline \multirow[t]{4}{*}{5} & Educational status & illiterate & 123 & 30.2 \\
\hline & & Primary & 48 & 11.8 \\
\hline & & Secondary & 99 & 24.3 \\
\hline & & Diploma and higher education & 137 & 33.7 \\
\hline \multirow[t]{3}{*}{6} & Religion & Muslim & 403 & 99 \\
\hline & & Orthodox & 2 & 0.5 \\
\hline & & Others & & 0.5 \\
\hline \multirow[t]{4}{*}{7} & Occupational status & House wife & 155 & 38.1 \\
\hline & & Government empoyee & 71 & 17.4 \\
\hline & & Student & 89 & 21.9 \\
\hline & & Daily worker & 83 & 20.4 \\
\hline \multirow[t]{3}{*}{8} & Monthly income & $1000-2500$ & 104 & 25.6 \\
\hline & & $2600-4400$ & 121 & 29.7 \\
\hline & & $>4500$ & 182 & 44.7 \\
\hline
\end{tabular}

\section{Knowledge of the study participants}

A total of $153(37.6 \%)$ respondents knew their own blood groups. Majority of the study participants $285(70 \%)$ knew that blood donor did not get an infection during blood donation process. Most of the respondents had adequate knowledge towards screening of donated blood such as HIV/AIDS and malaria before the blood transfusion $405(99.5 \%)$.Most of the respondents are aware of the risk of transmission of HIV/AIDS301(74\%), HBV 90(22.1\%), HCV $3(0.9 \%)$, Syphilis 5(1.5\%), and Malaria $8(2.3 \%)$ respectively.The respondents stated that the donation frequency annually was three times $117(28.8 \%)$, four times101 (24.9\%), two times $88(21.8 \%)$ and the remaining $74(18 \%)$ had no knowledge of this. Regarding to time interval between each donation of the study participants was every one month $18(4.4 \%)$, three months $182(44.7 \%)$, four months $145(35.6 \%)$ six months $54(13.3 \%)$, and the remaining $8(20 \%)$ had no knowledge of this. On knowledge of volume of blood collected in each process $214(52.6 \%)$ stated above $350 \mathrm{mls}, 111(27.3 \%)$ less than 350 millilitres, $80(19.7 \%)$, while $2(0.5 \%)$ express no knowledge of it (Table 3). 
Table3: Knowledge towards blood donation among adult population living in Jigjiga town, Ethiopia, 2019

S.N Variable

$1 \quad$ Knowledge of blood group

2 Can a person be infected during blood donation

3 Is donated blood screened by HIV/AIDS and malaria

4

Which disease can transmit for blood donation

5

How often can individual donate in ayear

6

Time between each donation
Category

Yes

No

Yes

No

Yes

No

HIV/AIDS

HBV

HCV

Syphilis

Malaria

Ones

Two times

Three times

Four times

Don,t know

Frequency $(n=407)$

153

259

122

285

405

2

301

90

3

5

5

8

28

88

117

101

One month 18

Three months 182

Four months 145

Six months

54

Don,t know

8

Percentage (\%)

37.6

64.1

30

70

99.5

0.5

74

22.1

0.9

1.5

2.3

6.9

21.6

28.8

24.9

19

4.4

44.7

35.6

13.3

2

26.8

17.7

47

6.1

2.2

52.6

27.3

19.7

0.5

2

119

29.2

133

32.6

$20 \mathrm{~min}$

155

38.1

10 Suatble age of blood donation

18-30

191

47

31-44

145

35.6

$>45$

71

17.5 


\section{Attitude of the study participants}

A total of 403 (99\%) respondents said blood donation is good and Voluntary donation was accepted as the best source of donor by 384(93.3\%), friendly donors by $18(4.4 \%)$, remunerated (paid) by $4(1.0 \%)$, and the remaining had no knowledge of it. A total of 393 (96.6\%) said something happen to a donor/ participants, $189(78.1 \%), 14(3.4 \%)$ stated that blood donor, become temporary weak and fall sick, might contract infection respectively. From the total respondents 397(97.5\%) said that the patient relatives should be asked to donate blood. Majority of the study participants $400(98.3 \%)$ stated that as they encourage their families and relatives to donate and $5(1.2 \%)$ reported pregnancy mother can donate the blood (Table4) shows the detail attitude level of the respondents regarding to blood donation.

Table 4:- Attitude towards blood donation among adult population living in Jigjiga town, 2019.

\begin{tabular}{|c|c|c|c|c|}
\hline S.N & Variable & Category & Frequency $(n=407)$ & $\begin{array}{l}\text { Percentage } \\
(\%)\end{array}$ \\
\hline \multirow[t]{3}{*}{1} & \multirow{3}{*}{$\begin{array}{l}\text { What do you think about blood } \\
\text { donation }\end{array}$} & Good & 403 & 99 \\
\hline & & Bad & 1 & 0.2 \\
\hline & & No idea & 3 & 0.7 \\
\hline \multirow[t]{4}{*}{2} & \multirow{4}{*}{$\begin{array}{l}\text { What do you think is the best source of } \\
\text { blood donation }\end{array}$} & Voluntary donor & 384 & 93.3 \\
\hline & & Friendly donor & 18 & 4.4 \\
\hline & & Rremunerated donor & 4 & 1.0 \\
\hline & & don't know & 1 & 0.2 \\
\hline \multirow[t]{3}{*}{3} & \multirow{3}{*}{$\begin{array}{l}\text { Can something harmful happen to a } \\
\text { blood donor during or after blood } \\
\text { donation }\end{array}$} & Yes & 133 & 32.7 \\
\hline & & No & 261 & 64.1 \\
\hline & & I don't know & 13 & 3.2 \\
\hline \multirow[t]{2}{*}{4} & \multirow{2}{*}{$\begin{array}{l}\text { Blood donation makes you weak and } \\
\text { sick }\end{array}$} & Yes & 318 & 78.1 \\
\hline & & No & 89 & 21.9 \\
\hline \multirow[t]{2}{*}{5} & \multirow{2}{*}{$\begin{array}{l}\text { What can happen blood donor during } \\
\text { and after blood donation }\end{array}$} & Contact infection & 14 & 3.4 \\
\hline & & Temporery weakness & 393 & 96.6 \\
\hline \multirow[t]{2}{*}{6} & \multirow[t]{2}{*}{ Blood donation can lead to anemia } & Yes & 89 & 21.8 \\
\hline & & No & 318 & 78.1 \\
\hline \multirow[t]{2}{*}{7} & \multirow{2}{*}{$\begin{array}{l}\text { Should patient relative be ask to } \\
\text { donate blood }\end{array}$} & Yes & 397 & 97.5 \\
\hline & & No & 9 & 2.2 \\
\hline \multirow[t]{3}{*}{8} & \multirow{3}{*}{$\begin{array}{l}\text { Do you encourage blood donation to } \\
\text { your relative }\end{array}$} & Yes & 400 & 98.3 \\
\hline & & No & 7 & 1.5 \\
\hline & & Yes & 5 & 1.2 \\
\hline \multirow[t]{2}{*}{9} & \multirow[t]{2}{*}{ Can a pregnancy women donate blood } & & & \\
\hline & & No & 402 & 98.8 \\
\hline
\end{tabular}

\section{Practice of the study participants}

A total of 77 study participants (18.9\%) have donated with $34(44.2 \%)$ one times, 27 (35.1\%) two times and $9(11.7 \%)$, $7(9.1 \%)$ more than three times respectively.Most $47(61 . \%)$ donated on friendly basis,25 (32.5\%) for a voluntary, $5(6.6 \%)$ to know their screening status respectively.330 respondents (81.1\%) had never donated blood in their life time. Reason for non donation included 189(46.4\%) not request to donate, unfit to donate 116 (28.5\%)fear of needle $90(22.1 \%)$, need to donate for relatives or friends in the future, $10(2.5 \%)$ and fear of knowing in my status, $2(0.5 \%)$ fear of knowing my screen status Table 5. 
Table 5: Practice towards blood donation among adult population living in Jigjiga town, Ethiopia, 2019.

\begin{tabular}{|c|c|c|c|c|}
\hline S.N & Variable & Category & Frequency $(n=407)$ & Percentage (\%) \\
\hline \multirow[t]{2}{*}{1} & \multirow[t]{2}{*}{$\begin{array}{l}\text { Have you ever donated blood in your } \\
\text { life time }\end{array}$} & Yes & 77 & 18.9 \\
\hline & & No & 330 & 81.1 \\
\hline \multirow[t]{4}{*}{2} & \multirow{4}{*}{$\begin{array}{l}\text { How many times you donated blood } \\
\text { in your life time }\end{array}$} & One time & 34 & 44.2 \\
\hline & & Two times & 27 & 35.1 \\
\hline & & Three times & 7 & 9.1 \\
\hline & & $\begin{array}{l}\text { More than three } \\
\text { times }\end{array}$ & 9 & 9.1 \\
\hline \multirow[t]{2}{*}{3} & \multirow[t]{2}{*}{$\begin{array}{l}\text { If an opportunity gives you would } \\
\text { like to donate blood }\end{array}$} & Yes & 367 & 90.2 \\
\hline & & No & 40 & 9.8 \\
\hline \multirow[t]{2}{*}{4} & \multirow[t]{2}{*}{$\begin{array}{l}\text { Would you like to be regular blood } \\
\text { donor in the future }\end{array}$} & Yes & 375 & 92.1 \\
\hline & & No & 32 & 7.9 \\
\hline \multirow[t]{2}{*}{5} & \multirow[t]{2}{*}{$\begin{array}{l}\text { Would you like to advice family and } \\
\text { friend for blood donation }\end{array}$} & Yes & 393 & 96.6 \\
\hline & & No & 14 & 3.4 \\
\hline \multirow[t]{3}{*}{6} & \multirow[t]{3}{*}{ Why did you donate } & Friendly & 47 & 61.0 \\
\hline & & Voluntry & 25 & 32.5 \\
\hline & & To know my status & 5 & 6.6 \\
\hline \multirow[t]{6}{*}{7} & \multirow{6}{*}{$\begin{array}{l}\text { If no what is the reason for not } \\
\text { donating the blood }\end{array}$} & Unfit to donate & 116 & 28.5 \\
\hline & & Need to donate & 10 & 2.5 \\
\hline & & friend in the future & 90 & 22.1 \\
\hline & & Fear of needle & 189 & 46.4 \\
\hline & & Not requested & & \\
\hline & & $\begin{array}{l}\text { Fear of knowing } \\
\text { mystatus }\end{array}$ & 2 & 0.5 \\
\hline
\end{tabular}

Table 6: Knowledge towards blood donation among adult population living in Jigjiga town, Ethiopia, 2019.

\begin{tabular}{lllll}
\hline S.N & Variable & Category & Frequency (n=407) & Percentage (\%) \\
\hline 1 & $\begin{array}{l}\text { Knowledge towards blood } \\
\text { donation }\end{array}$ & Good knowledge & 249 & 61.2 \\
& Poor knowledge & 158 & 38.8 \\
\hline
\end{tabular}

\section{Prevalence of knowledege towards blood donation}

The overall prevalence of the knowledge towards blood donation among adult population living in jigjiga town in this study was $61.2 \%$ (CI :( $56.3-65.8)$. (Table 6)

\section{Assessment of Knowledge towards a blood donation}

Knowledge about blood donation was assessed using 8 general questions which are deemed to be known by general population like can a person be infected during blood donation, is donated blood screened by HIV/AIDS and malaria before blood transfusion. Each response was scored as " 1 " for correct response and " 0 " for incorrect response.Knowledge scores for individuals were calculated and summed up to give the total knowledge score. Participants who correctly responded to more than $50 \%$ of knowledge assessing questions were considered as having 
adequate knowledge about blood donation, whereas those who scored $<50 \%$ were considered as having inadequate knowledge about blood donation(Table 7)

Table7: Knowledge assessment score towards blood donation among adult population living in Jigjiga town, Ethiopia, 2019.

S.N Knowledge assessment items Response

Correctly responded (\%) Incorrectly responded (\%)

1 Can person be infected during blood donation

2 How often can individual donate in a year

3 What is the time between each donation

4 Is donated blood screened by HIV/AIDS and malaria

5 Volume of each donation

6 Duration of donation process

7 Minimum weight for blood donation

8 How many lifes can each unit of blood can be saved
285(70)

122(30)

250 (61.4)

157(38.6)

182 (44.7)

$225(55.3)$

405 (99.5)

2 (0.5)

214 (52.6)

193 (47.4)

287 (70.5)

$120(29.5)$

400 (98.3)

7 (1.7)

$385(94.6)$

\section{Prevalence of attitude towards blood donation}

The overall prevalence of the attitude towards blood donationamong adult population in this study was 318 (78.1\%) (CI: (75.4 - 83.5)(Table 8).

Table 8: Attitude towards blood donation among adult population living in Jigjiga town, 2019.

\begin{tabular}{|c|c|c|c|c|}
\hline S.N & Variable & Category & Frequency $(\mathrm{n}=407)$ & Percentage (\%) \\
\hline \multirow[t]{2}{*}{1} & $\begin{array}{l}\text { Knowledge towards blood } \\
\text { donation }\end{array}$ & Good attitude & 318 & 78.1 \\
\hline & & Poor attitude & 89 & 21.9 \\
\hline
\end{tabular}

\section{Assessment of attitude towards blood donation.}

Similarly, 5 attitude related questions were asked, and the responses of each question were scored as " 1 " for correct response and "0" for incorrect response (Table 9). Attitude scores for individuals were calculated and summed up to give the total attitude score. Participants who correctly responded to more than $50 \%$ of attitude assessing questions were considered as having good attitude towards blood donation, whereas those who scored less than $50 \%$ were considered as having poor attitude towards blood donation.

Table 9: Attitude towards blood donation among adult population living in Jigjiga town, 2019.

\begin{tabular}{llll}
\hline S.N & Attitude assessment items. & \multicolumn{2}{c}{ Response } \\
& & Correctly responded \% & Incorrectly responded\% \\
\hline & & & $4(0.98)$ \\
1 & What do you think about blood donation & $403(99)$ & $23(5.7)$ \\
3 & What do you think is the best source of blood donation & $384(94.3)$ & $146(35.9)$ \\
4 & $\begin{array}{l}\text { Can some thing harmful happen to a blood donor during } \\
\text { and after blood donation }\end{array}$ & $261(64.1)$ & $89(21.9)$ \\
\hline & Blood donation leads to anemia & $318(78.1)$ & $318(78.1)$ \\
\hline
\end{tabular}




\section{Prevalence of practice towards blood donation.}

Only 77 (18.9\%) of study participants donated blood in their life , while majority $330(81.1 \%)$ of the respondents have not donated in their life(CI: $(15.2-22.9)$.

\section{Assessment of practice towards blood donation.}

The practice was assessed by asking about history of previous donation and the frequency of donation (Table 10). The practice was scored from largest (the number of times a donor donated previously) to smallest 0 (never donated before).

Table 10: Practice towards blood donation among adult population living in Jigjiga town, 2019.

\begin{tabular}{lllll}
\hline S.N & Variable & Category & Frequency $(\mathrm{n}=407)$ & Percentage (\%) \\
\hline 1 & Blood donation practice & Practice & 77 & 18.9 \\
& Not practice & 330 & 81.1 \\
& & & \\
\hline
\end{tabular}

\section{Reasons for not donating}

The main reasons given by the respondents for not donating blood was found to be not requested 189 (46.4\%) about blood donation and their feeling that they are medically unfit 116(28.5\%)(Figure 3)

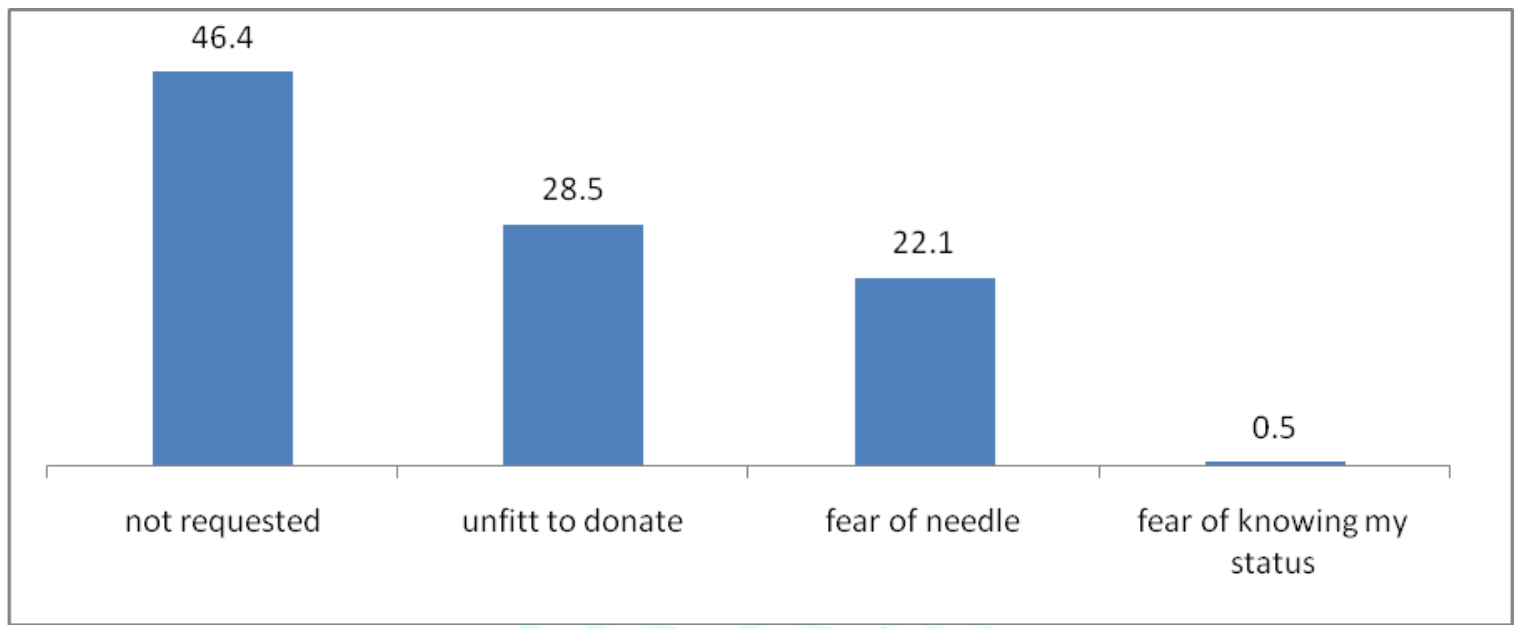

Figure 3: Reasons for not donating blood

\section{Factors Associated with Knowledge of blood donation}

\section{Bivariate analysis}

Bivariate analysis was conducted for socio demographic variables and knowledge towards blood donation. Bivariate analysis shows, occupation, age, educational status, and gender were significantly associated with adequate knowledge towards blood donation. Those variables which were with $\mathrm{p}$-values less than 0.05 at Bi-variate logistic regression were included in multiple logistic regressions (Table 11). 
Table11: Bivariate analysis of socio-demographic characteristics and an overall knowledge about blood donation among adult population living in jigjiga town, Ethiopia, 2019(407).

\begin{tabular}{|c|c|c|c|c|c|}
\hline \multirow[t]{2}{*}{ Variable } & \multirow[t]{2}{*}{ Category } & \multicolumn{2}{|c|}{ Knowledge status } & \multirow[t]{2}{*}{ COR(95\% CI) } & \multirow[t]{2}{*}{ P-value } \\
\hline & & $\operatorname{good} \%)$ & poor(\%) & & \\
\hline \multirow[t]{3}{*}{ Age } & $18-30$ & $133(57.6)$ & $98(42.4)$ & $0.429(0.213,0.863)$ & 0.059 \\
\hline & $31-45$ & $75(59.5)$ & $51(40.5)$ & $0.464(0.222,0.973)^{*}$ & 0.042 \\
\hline & $>45$ & $38(76)$ & $12(24)$ & 1.00 & \\
\hline \multirow[t]{2}{*}{ Sex } & Male & $133(66.8)$ & $66(33.2)$ & $1.694(1.133,2.532)^{*}$ & 0.010 \\
\hline & Female & $113(54.3)$ & $95(45.7)$ & 1.00 & \\
\hline \multirow[t]{4}{*}{ Ethnicity } & Somali & $236(60.1)$ & $157(39.9)$ & 1.00 & \\
\hline & Oromo & $2(66.7)$ & $1(33.3)$ & $1.331(0.120,14.798)$ & 0.816 \\
\hline & Amhara & $3(75)$ & $1(25)$ & $1.996(0.206,19.359)$ & 0.551 \\
\hline & others & $5(71.4)$ & $2(28.6$ & $1.663(0.319,8.679)$ & 0.546 \\
\hline \multirow{4}{*}{$\begin{array}{l}\text { Educational } \\
\text { level }\end{array}$} & illeterate & $65(52.8)$ & $58(47.2)$ & 1.00 & \\
\hline & primary & $23(47.9)$ & $25(52.1)$ & $0.821(0.421,1.601)$ & 0.563 \\
\hline & Secondary & $59(59.6)$ & $40(40.4)$ & $1.316(0.771,2.248)$ & 0.314 \\
\hline & $\begin{array}{l}\text { College and } \\
\text { higher }\end{array}$ & $99(72.3)$ & $38(27.7)$ & $2.325(1.389,3891)^{*}$ & 0.001 \\
\hline \multirow{5}{*}{$\begin{array}{l}\text { Occupational } \\
\text { status }\end{array}$} & Housewife & $76(49)$ & $79(51)$ & 1.00 & \\
\hline & $\begin{array}{l}\text { Governmentm } \\
\text { ployee }\end{array}$ & $54(76.1)$ & $17(23.9)$ & $3.302(1.759,6.197)^{*}$ & 0.000 \\
\hline & student & $53(59.6)$ & $36(40.4)$ & $1.530(0.903,2.594)$ & 0.114 \\
\hline & Daily worker & $57(68.7)$ & $26(31.3)$ & $2.279(1.301,3.992)^{*}$ & 0.004 \\
\hline & NGO & $6(66.7)$ & $3(33.3)$ & $2.079(0.502$ & 8.611 \\
\hline \multirow[t]{3}{*}{ Religion } & Muslim & $244(60.5)$ & $159(39.5)$ & 1.00 & \\
\hline & Orthodox & $1(50)$ & $1(50)$ & $0.652(0.040,10.493)$ & 0.763 \\
\hline & Others & $1(50)$ & $1(50)$ & $0.652(0.040,10.493$ & 0.763 \\
\hline \multirow{3}{*}{$\begin{array}{l}\text { Monthly } \\
\text { income }\end{array}$} & $1000-2500$ & $61(58.7)$ & $43(41.4)$ & 1.00 & \\
\hline & $2600-4400$ & $73(60.3)$ & $48(39.7)$ & $1.072(0.629,1.828)$ & 0.891 \\
\hline & $>4500$ & $112(61.5)$ & $70(38.5)$ & $1.128(0.690,1.844)$ & 0.631 \\
\hline \multirow[t]{4}{*}{ Marital status } & Married & $146(57.7)$ & $107(42.3)$ & 1.00 & \\
\hline & Single & $95(64.6)$ & $52(35.4)$ & $1.339(0.880,2.038)$ & 0.173 \\
\hline & Dicorced & $4(80)$ & $1(20)$ & $2.932(0.323,26.602)$ & 0.339 \\
\hline & Widowed & $1(50)$ & $1(50)$ & $0.733(0.45,11.849)$ & 11.849 \\
\hline
\end{tabular}

CI= Confidence Interval, COR= Crude Odd Ratio; ${ }^{*}=p$-value $<0.05,1=$ reference

\section{Factors Associated with Knowledge of blood donation}

\section{Multivariate analysis}

To minimize the risk of confounder for dependent variables multiple logistic regressions were used. The result of multiple logistic regression model showed that age, education, and occupational status of the respondent were associated significantly with knowledge of blood donation. Those who were in college and higher education were two times knowledgable than (AOR=2.034, 95\%CI: ((1.1283.669)) those in secondary and primary education respondents
$(\mathrm{AOR}=1.240, \quad 95 \% \mathrm{CI}:(0.673, \quad 2.284) \quad$,(AOR=0.778, $95 \% \mathrm{CI}:(0.391,1.546)$ respectively.

A sstudy participants who were government employees and daily workers weretwo times (AOR=2.259, 95\% CI:(1.103, 4.629), (AOR=2.029, 95\% CI:( 1.084, 3.798) more knowledgable than students(AOR $=2.259,95 \%$ CI: ( $(1.103$, 4.629)). A study particpants age range between 18-30 were less likely to have knowledge towards blood donation $59.2 \%$ times (AOR=0.408, 95\% CI: ((0.194, 0.858)) (Table 12). 
Table12: Multivariate analysis of socio-demographic characteristics and an overall knowledge about blood donation among adult population living in jigjiga town, Ethiopia, 2019(407).

\begin{tabular}{|c|c|c|c|c|c|c|}
\hline & \multirow{2}{*}{ Variable } & \multirow{2}{*}{ Category } & \multicolumn{2}{|c|}{ Knowledge category } & \multirow{2}{*}{ AOR(95\% CI) } & \multirow{2}{*}{ P-value } \\
\hline & & & $\operatorname{good} \%)$ & poor $(\%)$ & & \\
\hline \multirow[t]{3}{*}{1} & \multirow[t]{3}{*}{ Age } & $18-30$ & $133(57.6)$ & $98(42.4)$ & $0.429(0.213,0.863)$ & $0.018^{*}$ \\
\hline & & $31-45$ & $75(59.5)$ & $51(40.5)$ & $0.464(0.222,0.973)$ & 0.055 \\
\hline & & $>45$ & $38(76)$ & $12(24)$ & 1.00 & \\
\hline \multirow[t]{4}{*}{2} & \multirow[t]{2}{*}{ Sex } & Male & $133(66.8)$ & $66(33.2)$ & $1.064(0.660-1.713)$ & 0.800 \\
\hline & & Female & $113(54.3)$ & $95(45.7)$ & 1.00 & \\
\hline & \multirow{4}{*}{$\begin{array}{l}\text { Educational } \\
\text { level }\end{array}$} & illeterate & $65(52.8)$ & $58(47.2)$ & 1.00 & \\
\hline & & primary & $23(47.9)$ & $25(52.1)$ & $0.778(0.391,1.546)$ & 0.475 \\
\hline \multirow[t]{2}{*}{3} & & Secondary & $59(59.6)$ & $40(40.4)$ & $1.240(0.673-2.284)$ & 0.490 \\
\hline & & College and higher & $99(72.3)$ & $38(27.7)$ & $2.034(1.128-3.669)^{*}$ & 0.018 \\
\hline \multirow[t]{5}{*}{4} & \multirow{5}{*}{$\begin{array}{l}\text { Occupational } \\
\text { status }\end{array}$} & Housewife & $76(49)$ & $79(51)$ & 1.00 & \\
\hline & & Governmenemployee & $54(76.1)$ & $17(23.9)$ & $2.259(1.103-4.629)^{*}$ & 0.026 \\
\hline & & student & $53(59.6)$ & $36(40.4)$ & $1.291(0.690-2.414$ & 0.424 \\
\hline & & Daily worker & $57(68.7)$ & $26(31.3)$ & $2.029(1.084-3.798)^{*}$ & 0.027 \\
\hline & & NGO & $6(66.7)$ & $3(33.3)$ & $1.732(0.387-7.743)$ & 0.472 \\
\hline
\end{tabular}

AOR= Adjusted Odd Ratio; $C I=$ Confidence Interval, ${ }^{*}=p$-value $<0.05,1=$ reference

Factors Associated with attitude of blood donation

\section{Bivariate analysis}

Bivariate analysis was conducted for socio demographic variables and attitude towards blood donation. Bivariate analysis shows, age, educational, occupational status were significantly associated with good attitude towards blood donation.(Table 13).

Table13: Bivariate analysis of socio demographic characteristics and an overall attitude about blood donation among adult population in jigjiga town, Ethiopia, 2019(407).

\begin{tabular}{|c|c|c|c|c|c|c|}
\hline $\mathrm{S} / \mathrm{n}$ & Variable & Category & $\begin{array}{l}\text { Attitude status } \\
\text { Good(\%) }\end{array}$ & Poor(\%) & $\operatorname{COR}(95 \% \mathrm{CI})$ & P-value \\
\hline \multirow[t]{3}{*}{1} & Age & $18-30$ & $180(77.9)$ & $51(22.1)$ & 1.00 & \\
\hline & & $31-45$ & $91(72.2)$ & $35(27.8)$ & $0.737(0.447,1.213)$ & 0.230 \\
\hline & & $>45$ & $47(94)$ & $3(6)$ & $4.439(1.327,14.854)^{*}$ & 0.016 \\
\hline \multirow[t]{2}{*}{2} & Sex & Male & $161(80.9)$ & $38(19.1)$ & $1.376(0.857,2.211)$ & 0.187 \\
\hline & & Female & $157(75.5)$ & $51(24.5)$ & 1.00 & \\
\hline \multirow[t]{4}{*}{3} & Ethnicity & Somali & $309(78.8)$ & $84(21.4)$ & 1.00 & \\
\hline & & Oromo & 2 (66.7) & $1(33.3)$ & $0.544(0.049,6.069)$ & 0.621 \\
\hline & & Amhara & $4(100)$ & $0(0.0)$ & & \\
\hline & & Others & $3(42.9)$ & $4(57.1)$ & & \\
\hline \multirow[t]{4}{*}{4} & Educational & Illeterate & $80(65)$ & $43(35)$ & 1.00 & \\
\hline & level & Primary & $40(83.3)$ & $8(16.7)$ & $2.687(1.155,6.255)^{*}$ & 0.022 \\
\hline & & Secondary & $84(84.8)$ & $15(15.2)$ & $3.010(1.552,5.840)^{*}$ & 0.001 \\
\hline & & $\begin{array}{l}\text { College and } \\
\text { higher }\end{array}$ & $114(83.2)$ & $23(16.8)$ & $2.664(1.489,4.765)^{*}$ & 0.001 \\
\hline \multirow[t]{5}{*}{5} & Occupational & House wife & $112(72.3)$ & $43(27.7)$ & 1.00 & \\
\hline & status & $\begin{array}{l}\text { Governmen } \\
\text { employee }\end{array}$ & $56(78.9)$ & $15(21.1)$ & $2.645(1.209,5.785)^{*}$ & 0.015 \\
\hline & & Student & $79(88.8)$ & $10(11.2)$ & $3.033(1.439,6.395)^{*}$ & 0.004 \\
\hline & & Daily worke & $64(77.1)$ & $19(22.9)$ & $1.293(0.695,2.407)^{*}$ & 0.417 \\
\hline & & NGO & $7(77.8)$ & $2(22.2)$ & $1.344(0.269,6.725)$ & 0.719 \\
\hline \multirow[t]{3}{*}{6} & Religion & Muslim & $316(78.4)$ & $87(21.6)$ & 1.00 & \\
\hline & & Orthodox & $1(50)$ & $1(50)$ & $0.252(0.016,4.065)$ & 0.331 \\
\hline & & Others & $1(50)$ & $1(50)$ & $0.252(0.016,4.065)$ & 0.331 \\
\hline \multirow[t]{3}{*}{7} & Monthly & $1000-2500$ & $83(79.8)$ & $21(20.2)$ & 1.00 & \\
\hline & income & $2600-4400$ & $93(76.9)$ & $28(23.1)$ & $0.870(0.453,1.671)$ & 0.676 \\
\hline & & $>4500$ & $142(78)$ & $40(22)$ & $0.933(0.509,1.712)$ & 0.823 \\
\hline \multirow[t]{4}{*}{8} & Marital status & Married & $189(74.7)$ & $64(25.3)$ & & \\
\hline & & Single & $122(83)$ & $25(17)$ & & \\
\hline & & Divorce & $5(100)$ & $0(0.0)$ & & \\
\hline & & Widowed & $2(100)$ & $0(0.0)$ & 1.00 & \\
\hline
\end{tabular}

CI= Confidence Interval, COR= Crude Odd Ratio; * ${ }^{*}$-value $<0.05,1=$ reference 


\section{Factors Associated with attitude of blood donation}

\section{Multivariate analysis}

In bivariate logistic regression age, education, and occupational status were significantly associated with attitude of the participants, while in multivariate logistic regression education level was significantly associated with atitude towards blood donation. Those respondents who are college and higher education and secondary were 2.450 times more likely (AOR=2.450,95\% CI:((1.038 - 5.782)) , $2.359(\mathrm{AOR}=2.359,95 \% \mathrm{CI}:(1.180-4.7170))$ to have good attitude towards blood donation compared to primary school $2.161 \quad(\mathrm{AOR}=2.161, \quad 95 \% \mathrm{CI}:((1.039-4.495))$ respectively (Table14).

Table14: Multivariate analysis of socio-demographic characteristics and an overall attitude about blood donation among adult population living in jigjiga town, Ethiopia, 2019.

\begin{tabular}{|c|c|c|c|c|c|c|}
\hline \multirow[t]{2}{*}{ S.N. } & \multirow[t]{2}{*}{ Variable } & \multirow[t]{2}{*}{ Category } & \multicolumn{2}{|c|}{ Attitude status } & \multirow[t]{2}{*}{$\operatorname{AOR}(95 \% \mathrm{CI})$} & \multirow[t]{2}{*}{ P-value } \\
\hline & & & $\operatorname{good} \%)$ & poor $(\%)$ & & \\
\hline \multirow[t]{3}{*}{1} & Age & $18-30$ & $180(77.9)$ & $51(22.1)$ & 1.00 & \\
\hline & & $31-45$ & $91(72.2)$ & 35 (27.8) & $0.226(0.066-0.774)$ & $0.018 \$$ \\
\hline & & $>45$ & 47 (94) & $3(6)$ & $0.209(0.059-0.737)$ & $0.018 \$$ \\
\hline \multirow[t]{4}{*}{2} & Educational level & illeterate & $80(65)$ & $43(35)$ & 1.00 & \\
\hline & & primary & $40(83.3)$ & $8(16.7)$ & $2.450(1.038-5.782)^{*}$ & 0.041 \\
\hline & & Secondary & $84(84.8)$ & $15(15.2)$ & $2.161(1.039-4.495)^{*}$ & 0.039 \\
\hline & & College and higher & $114(83.2)$ & $23(16.8)$ & $2.359(1.180-4.717) *$ & 0.015 \\
\hline \multirow[t]{5}{*}{3} & Occupational status & House wife & $112(72.3)$ & $43(27.7)$ & 1.00 & \\
\hline & & $\begin{array}{l}\text { Government } \\
\text { employee }\end{array}$ & $56(78.9)$ & $15(21.1)$ & $2.022(0.828-4.940)$ & 0.122 \\
\hline & & Student & $79(88.8)$ & $10(11.2)$ & $2.086(0.889-4.940$ & 0.091 \\
\hline & & Daily worke & $64(77.1)$ & $19(22.9)$ & $1.181(0.215-6.476)$ & 0.699 \\
\hline & & NGO & $7(77.8)$ & $2(22.2)$ & $0.978(0.543-1.761)$ & 0.942 \\
\hline
\end{tabular}

AOR = Adjusted Odd Ratio; $C I=$ Confidence Interval, ${ }^{*}=p$-value $<0.05,1=$ reference

\section{Factors Associated with practice of blood donation}

\section{Bivariate analysis}

Variables that are significantly associated in bivariable

logistic regression analysis only with practice of blood donation were, gender (male), higher education, occupational status (government employee, students, daily workers, NGO workers) respectively(Table 15) .

Table15: Bivariate analysis of socio-demographic charactresitics and practice of adult population towards blood donation living Jigjiga town, Ethiopia 2019 ( $n=407)$.

\begin{tabular}{|c|c|c|c|c|c|c|}
\hline \multirow[t]{2}{*}{$\mathrm{S} / \mathrm{N}$} & \multirow[t]{2}{*}{ Variable } & \multirow[t]{2}{*}{ Category } & \multicolumn{2}{|c|}{ Practice category } & \multirow[t]{2}{*}{ COR(95\% CI) } & \multirow[t]{2}{*}{ P-value } \\
\hline & & & Practice (\%) & Not practice (\%) & & \\
\hline \multirow[t]{3}{*}{1} & \multirow[t]{3}{*}{ Age } & $18-30$ & $44(19.0)$ & $187(81.0)$ & 1.00 & \\
\hline & & $31-45$ & $22(17.5)$ & $104(82.5)$ & $0.834(0.396,1758)$ & 0.634 \\
\hline & & $>45$ & $11(22)$ & $39(78)$ & $0.750(0.333,1.689)$ & 0.487 \\
\hline \multirow[t]{2}{*}{2} & \multirow[t]{2}{*}{ Sex } & Male & $65(32.7)$ & $134(67.3)$ & $7.923(4.120,15.235)^{*}$ & 0.000 \\
\hline & & Female & $12(5.8)$ & $196(94.2)$ & 1.00 & \\
\hline \multirow[t]{4}{*}{3} & \multirow[t]{4}{*}{ Ethnicity } & Somali & $74(18.8)$ & $319(81.2)$ & $0.580(0.110,3.048)$ & 0.520 \\
\hline & & Oromo & $0(0.0)$ & $3(100)$ & 0.000 & \\
\hline & & Amhara & $1(25)$ & $3(75)$ & $0.833(0.051,13,633)$ & 0.898 \\
\hline & & others & $2(28.6)$ & $5(71.4)$ & 1.00 & \\
\hline \multirow[t]{2}{*}{4} & \multirow{4}{*}{$\begin{array}{l}\text { Educational } \\
\text { level }\end{array}$} & illeterate & $10(8.1)$ & $113(91.9)$ & 1.00 & \\
\hline & & primary & $3(6.3)$ & $45(93.7)$ & $0.753(0.198,2.865)$ & 0.678 \\
\hline \multirow[t]{2}{*}{5} & & Secondary & $16(16.2)$ & $83(83.7)$ & $2.178(0.941,5.043)$ & 0.069 \\
\hline & & College and higher & $48(35)$ & $89(65)$ & $6.094(2.920,12.719) *$ & 0.000 \\
\hline \multirow[t]{5}{*}{6} & \multirow{5}{*}{$\begin{array}{l}\text { Occupational } \\
\text { status }\end{array}$} & Housewife & $7(4.5)$ & $148(95.5)$ & 1.00 & \\
\hline & & $\begin{array}{l}\text { Governmen } \\
\text { employee }\end{array}$ & $28(39.4)$ & $43(60.6$ & $13.767(5.625,33.698)^{*}$ & 0.000 \\
\hline & & Student & $20(22.5)$ & $69(77.5)$ & $6.128(2.474,15.178)^{*}$ & 0.000 \\
\hline & & Daily worker & $17(20.5)$ & $66(79.5)$ & $5.446(2.156,13.758)^{*}$ & 0.000 \\
\hline & & NGO & $5(55.6)$ & $4(44.4)$ & $26.429(5.794,120.559)^{*}$ & 0.000 \\
\hline \multirow[t]{3}{*}{7} & \multirow[t]{3}{*}{ Religion } & Muslim & $74(18.4)$ & $329(81.6)$ & 1.00 & \\
\hline & & Orthodox & $2(50)$ & $0(0.0)$ & & \\
\hline & & Others & $1(50)$ & $1(50)$ & & \\
\hline \multirow[t]{3}{*}{8} & \multirow{3}{*}{$\begin{array}{l}\text { Monthly } \\
\text { income }\end{array}$} & $1000-2500$ & $22(21.2)$ & $82(78.8)$ & 1.00 & \\
\hline & & $2600-4400$ & $19(15.7)$ & $102(84.3)$ & $0.694(0.352,1.369)$ & 0.292 \\
\hline & & $>4500$ & $36(19.8)$ & $146(80.2)$ & $0.919(0.507,1.667$ & 0.781 \\
\hline
\end{tabular}




\section{Factors Associated with practice of blood donation}

Multivariate analysis.

In bivariate logistic regression analysis, age, sex, education, occupational status were statistically associated with blood donation practice of the respondents, while in multivariate logistic regression analysis, participant' sex, education , and occupational status were found to be significantly associated with practice of blood donation.Those participants, NGO workers were more likely to donate blood eight times higher than $(A O R=8.167,95 \% \mathrm{CI}:(1.530,43.592)$ as compared to government employees (AOR $=4.812$, 95\% CI: (1.79512.901) and students (AOR=3.336, 95\% CI:(1.198- 9.289) respectively. Male participants were more likely to donate blood five times (AOR=5.245,95\% CI:((2.556 -10.763)) higher than female for blood donation. In addition to this, those respondents who were graduated from college and higher education were more likely to donate blood than others 3.247 (AOR=3.247, 95\% CI: ((1.408 -7.489)) Table 16 .

Table16: Multi-variate analysis of socio-demographic characterisitics and practice of adult population towards blood donation living in Jigjiga town, Ethiopia $2019(n=407)$.

\begin{tabular}{|c|c|c|c|c|c|c|}
\hline \multirow[t]{2}{*}{ S No } & \multirow[t]{2}{*}{ Variable } & \multirow[t]{2}{*}{ Category } & \multicolumn{2}{|c|}{ Practice category } & \multirow[t]{2}{*}{$\operatorname{AOR}(95 \% \mathrm{CI})$} & \multirow[t]{2}{*}{ P-value } \\
\hline & & & Practice (\%) & Not practice (\%) & & \\
\hline \multirow[t]{2}{*}{1} & \multirow[t]{2}{*}{ Sex } & Male & $65(32.7)$ & $134(67.3)$ & $5.245(2.556-10.763)^{*}$ & 0.0001 \\
\hline & & Female & $12(5.8)$ & $196(94.2)$ & 1.00 & \\
\hline \multirow[t]{4}{*}{2} & \multirow{4}{*}{$\begin{array}{l}\text { Educational } \\
\text { level }\end{array}$} & illeterate & $10(8.1)$ & $113(91.9)$ & 1.00 & \\
\hline & & primary & $3(6.3)$ & $45(93.7)$ & $0.643(0.159-2.597)$ & 0.535 \\
\hline & & Secondary & $16(16.2)$ & 83(83.7) & $1.108(0.425-2.887)$ & 0.833 \\
\hline & & $\begin{array}{l}\text { College and } \\
\text { higher }\end{array}$ & $48(35)$ & $89(65)$ & $3.293(1.421-7.631)^{*}$ & 0.005 \\
\hline \multirow[t]{5}{*}{3} & \multirow{5}{*}{$\begin{array}{l}\text { Occupational } \\
\text { status }\end{array}$} & Housewife & $7(4.5)$ & $148(95.5)$ & 1.00 & \\
\hline & & $\begin{array}{l}\text { Governmen } \\
\text { employee }\end{array}$ & $28(39.4)$ & $43(60.6$ & $4.812(1.795-12.901)^{*}$ & 0.002 \\
\hline & & Student & $20(22.5)$ & $69(77.5)$ & 3.336 (1.198- 9.289)* & 0.021 \\
\hline & & Daily work & $17(20.5)$ & $66(79.5)$ & 2.517 (0.917- 6.907 & 0.073 \\
\hline & & NGO & $5(55.6)$ & $4(44.4)$ & $8.932(1.631-48.923)^{*}$ & 0.012 \\
\hline
\end{tabular}

AOR=adjusted odds ratio, $C I=$ Confidence Interval, ${ }^{*}=p$-value $<0.05,1=$ reference

\section{DISCUSSION}

In this study the researchers tried to investigate the level and factors associated with knowledge, attitude, and practice of adults'population towards blood donation in Jigjiga town. A total of study participants, 249(61.2\%)(CI: (56.3 - 65.8) had adequate knowledge regarding blood donation. This study is higher than a community based Cross-sectional study conducted in Harar town which was aimed to assess the level of knowledge, attitude and practice of voluntary blood donation among total of 845 participants which reported that $43.5 \%$ of them had adequate knowledge towards blood donation ${ }^{39}$. The possible reason for this discrepancy might be due to the difference in the sample size.On the other hand this result is contemporary to study conducted in Debremarkos town which was aimed to assess level of Knowledge, attitude and practice towards blood donation and associated factors which shows overall level of knowledge towards blood donation was found to be 56.5 $\% 40$.

In the current study, multivariate logistic regression showed that education, occupational status was the variables that significantly associated with the knowledge of participants. Participants who attended college and higher education $(\mathrm{AOR}=2.034 ; 95 \% \mathrm{CI}: 1.128 ; 3.669)$ were more likely to have adequate knowledge towards blood donation. So ,as the level of education increases, participants' knowledge towards blood donation also increases.On the other hand government employees participants and daily workers $(\mathrm{AOR}=2.259 ; 95 \%$ CI:1.103, 4.629) , (AOR=2,029, 95\% CI:1.084- 3.798), were more likely to have adequate knowledge towards blood donation than students (AOR=1.291, 95\% CI: 0.690- 2.414) respectively. Majority 318 (78.1\%)(CI: $(75.4-83.5)$ of the study participants have good attitude towards blood donation. This study is comparable to other study conducted in Gondar town in which majority $630(82 \%)$ of the study participants have good attitude towards blood donation ${ }^{10}$ However, it is higher than study done in Harar town which shows among the 845 study respondents, only $278(32.9 \%)$ had positive attitude toward voluntary blood donation.

But this study is lower than studies done among University Students in Kilimanjaro, Tanzania which revealed majority of the participants (93\%) had positive attitudes towards blood donation 41 total of 403 (99\%) respondents report blood donation is good and Voluntary blood donation was the most important source of donor by 384(93.3\%), friendly donors by $18(4.4 \%)$, remunerated (paid) by $4(1.0 \%)$, and the remaining had poor attitude of it. Majority 318 (78.1\%) of them reported blood donation cannot lead to anemia.This result is opposite with a study conducted in Gonder City in which $282(36.7 \%)$ of them had a perception that blood donation causes anemia ${ }^{10}$. The possible reason for this 
discrepancy might be due to the difference in the sociocultural factors. In this study, education was the only variable which significantly associated with the attitude of the participants using multivariate logistic regression. Those participants who were college and higher education (AOR = 2.450; 95\% CI: 1.038, 5.782) were more likely to have good attitude towards blood donation.In the current study only18.9\%(CI: (15.2 - 22.9) of them have donated blood in the past, out of which $47(61 \%)$ donated to friends or relatives, $25(32.5 \%)$ voluntarily, $5(6.6 \%)$ to know their screening status respectively. Majority of the study participants donated $34(44 \%)$ one time, 27 (35.1\%) two times and 9 (11.7\%), 7 (9.1) more than three times respectively. In this study, multivariate logistic regression showed gender, education and occupational status was the variables that significantly associated with the practice of blood donation.In this study, more than half, 65 (32.7\%), of donors were male.

The result is in line with a study conducted in Gondar town which showed that majority 94 (66.6\%), of blood donors were male ${ }^{10}$. Males were five times more likely to donate blood compared to females (AOR $=5.245,95 \% \mathrm{CI}:(2.556$ 10.763). This finding is also inline with a study conducted among Healthcare Workers at the University of Benin Teaching Hospital, Benin City, Nigeria which reported, only $22.1 \%$ of them have donated blood in the past, out of which $52.8 \%$ were as family replacement and $41.7 \%$ voluntary ${ }^{42}$. This finding was supported by a study conducted in Harar, Debremarkos and among university students in Saudi Arabia which revealed only 191 (22.6\%) $124(16.1 \%)$ and $62(19.02 \%)$ were donors, respondents had donated blood before the study period respectively ${ }^{10,43}$. This finding is lower than a study conducted in Arsi university and Adama science and technology university which revealed 27.2\% Health Science students have donated blood in their life time. The possible reason for this difference may be due to level of educationa and matter of health experience towards blood donation.

The major reason given by those who had never donated was that no one requested 189 (46.4\%) about blood donation and their feeling that they are medically unfit $116(28.5 \%)$ respectively. Those respondents who are graduated college and higher education were more likely to donate blood than others 3.247 (AOR=3.247, 95\% CI: ((1.408 -7.489)). Being NGO worker were significantly associated to practice of blood donation in this study.

Those participants who are NGO workers were more likely to donate blood eight times higher than (AOR=8.167, 95\% CI: $(1.530,43.592))$ as compared to government employees $(\mathrm{AOR}=4.812,95 \%$ CI: (1.795- 12.901) and students (AOR=3.336, 95\% CI: (1.198- 9.289) respectively.

\section{CONCLUSION}

In general, the study showed that the proportion of adults who had adequate level of knowledge about blood donation and good attitude towards blood donation is high. However, the level of blood donation practice was low; and perception like not requested, not being fitted to donate blood, fear of needle during blood donation, were the major reason for not donating blood. College and higher education, occupational status, particulaly government workers remained to be significantly associated with knowledge towards blood donation. Regarding factors affecting attitude towards blood donation, education was the only variable which remained to be significantly associated with attitude. Besides sex, education, and occupational status were statistically significant variables that increase blood donation practice.

\section{REFERENCES}

1.Urgesa K, Hassen N, Seyoum A. Medicine Net.com. Medterms Medical Dictionary Blood Medicine.2017

2.Urgesa K, Hassen N, Seyoum A. WHO. Towards 100\% Voluntary Blood Donation: A Global Framework for Action. Blood Medicine. 2017.

3.Amatya M. Study on knowledge, attitude and practice of blood donation among students of different colleges of Kathmandu,Nepal. International Journal of Pharmaceutical and Biological Archives.2013; 4: 3

4.Olubiyi SK, F. R. Babalola, Olubiyi MV, Umar NJ,Ibraheem MA. "Knowledge, attitudes and practices of blood donation among adults in Ado-Ekiti, Nigeria. Sky Journal of Medicine and Medical Sciences.2014; 2:7.

5.Nwabueze, Nnebue, AEzenyeaku, Aniagboso, Ezemonye, Azuike D. Blood Donation. Microsoft Corporation, Redmond. 2007.

6.Nwabueze SA, Nnebue CC, ECA, Ezenyeaku CA, Aniagboso CC, Ezemonye OE. Canadian Surgeon and the Introduction of Blood Transfusion in War Surgery. Transfusion. 2008.

7.Nwabueze SA, Nnebue CC, Azuike EC, Ezenyeaku CA, Aniagboso CC, Ezemonye OE, et al. Volume of Blood in a Human. 2014.

8.WHO(2010). World Blood Donor Day: New Blood for the World, WHO, Geneva, Switzerland.

9.WHO.Blood safety and availability: a fact sheet of WHO Media Center.2015

10.Melku M, Terefe B, Asrie F, Enawgaw B, Melak T, Tsegay YG, et al. Knowledge, Attitude, and Practice of Adult Population towards Blood Donation in Gondar Town, Northwest Ethiopia: A Community Based Cross-Sectional Study. Hindawi Publishing Corporation Journal of Blood Transfusion.2016.

11.Tapko JB, BT, Sambo LG. Status of Blood Safety in the WHO African Region:. World Health Organization Regional Office for Africa, Brazzaville. 2014.

12.Al-Asadi JN, Al-Yassen AQ. Fordham J and Dhingra N. Towards $100 \%$ voluntary blood donation. 2018.

13.Urgesa K, Hassen N, Seyoum A. Karim AM, Admassu K, Schellenberg J, et al. Effect of Ethiopia's health extension program on maternal and newborn health care practices in 101 rural districts. Blood Medicine. 2013.

14.Urgesa K, Hassen N, Seyoum A. WHO. Safety WB, Availability-Fact sheet N. 279. 2014. Available from . January 10.2017

15.Yenework, Jemberu A, Esmael A, Y K, Ahmed(2014). Blood safety and availability. BMC. June.

16.Gebresilase HW, Fite RO, Abeya SG. Behavioral and infectious disease risks in young blood donors: implications for recruitment. Transfusion. BMC.2003; 43(11):1596-603.

17.Jemberu YA, Esmael A, Ahmed KY. World Health organization. Making Safe Blood Available in Africa, vol. Geneva: Statement by Coordinator. BMC. 2006

18.Melku M, Terefe B, Asrie F, Enawgaw B, Melak T, Tsegay YG, et al. The challengesofmeeting theblood transfusion requirements in Sub-Saharan Africa: the need for the development of alternatives to allogenic blood,. Journal ofBlood Medicine. vol. 2.2011.

19.Mohammed S, Essel HB. WHO Campaign Essentials: World Blood Donor Day Geneva BMC. 2014

20.Jemal S, Shukure R. WHO AFRO: Blood safety. Blood Disorders and Medicine.2013.

21.Jemal S, Shukure R. Blood transfusion in Ethiopia. 1998.

22.Gebresilase HW, Fite RO, Abeya SG. Knowledge, Attitude and practice on blood donation among Dhaka university students in Bangladesh. East Africa.1997

23.Gebresilase HW, Fite RO, Abeya SG. WHOTowards 100\% voluntary blood donation a global framework for action. . 17 March.2016.

24.Gebresilase HW, Fite RO, Abeya SG. Convenience, the bane of our existence, and other barriers to donatingTransfusion. BMC.2006.

25.Gebresilase HW, Fite RO, Abeya SG. Study on awareness and perceptions regarding blood safety and blood donation among health care providers in a teaching hospital of Calcutta. Indian J Community MedBMC.2001.

26.Gebresilase HW, Fite RO, Abeya SG. Comparative Study on Knowledge Attitude and Practice regarding Blood Donation in Rural and Urban area of Bangalore Health Sciences.2015.

27.Urgesa K, Hassen N, Seyoum A. About $40 \%$ of Ethiopian Mothers Die because of Lack of Enough Blood Donors. BMC.2014. 
28.Urgesa K, Hassen N, Seyoum A. WHO. Ethiopia Commences World Blood Donor Day 2014 CelebrationsBMC. 2014.

29.Jemberu YA, Esmael A, Ahmed KY(2011). World Health Organization. WHO Global Data Base on Blood Safety, Summary Report.

30.Jemberu YA, Esmael A, Ahmed KY. Blood safety and availability. Jun. 2014.

31.Urgesa K, Hassen N, Seyoum A. WHO. Ethiopia Commences World Blood Donor Day 2014 Celebrations .

32.Urgesa K, Hassen N, Seyoum A. ENSA. About 40\% of Ethiopian Mothers Die because of Lack of Enough Blood Donors.2014.

33.Gebresilase HW, Fite RO, Abeya SG(2016). World Health Organization. Blood safety and availability. WHO Fact Sheet.. 17 March 2016

34.Gebresilase HW, Fite RO, Abeya SG. The United States potential blood donor pool: estimating the prevalence of donor-exclusion factors on the pool of potential donors. Transfusion. 2007.

35.Elias E, WilhellmussMauka, Philemon RN, Damian DJ, J.Mahande M, Msuya SE. WHO, Voluntary unpaid blood donations must increase rapidly to meet 2020 goa. Hindawi Publishing Corporation. Article ID 8546803,2016; 8.

36.Melku M, Terefe B, Asrie F, Enawgaw B, Melak T, Tsegay YG, et al(2013). The knowledge, attitude and practice towards blood donation among voluntary blood donors in chennai, indiaClinical and Diagnostic. 2013; 76.

37.Melku M, Terefe B, Asrie F, Enawgaw B, Melak T, Tsegay YG, et al(2010). Payment, compensation and replacement-the ethics and motivation of blood and plasma donation. Hindawi Publishing Corporation.2010; 99(3):202-211.

38. Urgesa K, Hassen N, Seyoum A. Knowledge, attitude, and practice regarding voluntary blood donation among adult residents of Harar town. Blood Medicine. 2017.

39.Urgesa K, Hassen N, Seyoum A(2017). Knowledge, attitude, and practice regarding voluntary blood donation among adult residents of Harar town, Eastern Ethiopia. Blood Medicine.2017

40.Jemberu YA, Esmael A, Ahmed KY. Knowledge, attitude and practice towards blood donation and associated factors among adults in Debre Markos town,. BMC hematolgy. 2016.

41.Elias E, WilhellmussMauka, Philemon RN, Damian DJ, J.Mahande M, Msuya SE. Knowledge, Attitudes, Practices, and Factors Associatedwith Voluntary Blood Donation among University Students inKilimanjaro, Tanzania Hindawi Publishing Corporation Journal of Blood Transfusion.2016.

42.Nwogoh B, Aigberadion U, Nwannadi AI. Knowledge, Attitude, and Practice of Voluntary Blood Donation among Healthcare Workers at the University of Benin TeachingHospital, Benin City, Nigeria. Hindawi Publishing Corporation Journal of Blood Transfusion. 2013.

43.Urgesa K, Hassen N, Seyoum A. Knowledge, attitude, and practice regarding voluntary blood donation among adult residents of Harar town, Eastern Ethiopia: a community-based study. Blood Medicine. 2017. 